Dr DRAGAN BOGETIĆ, naučni savetnik

Institut za savremenu istoriju

Beograd, Trg Nikole Pašića 11

dbogetic@gmail.com

UDK 94:327(497.1)"1964"(093.2)

originalan naučni rad

327.55:341.181(620)"1964"(093.2)

primljeno: 17. januar 2017.

prihvaćeno: 17. maj 2017.

\title{
SUKOB TITOVOG KONCEPTA UNIVERZALIZMA I SUKARNOVOG KONCEPTA REGIONALIZMA NA SAMITU NESVRSTANIH U KAIRU 1964.*
}

APSTRAKT: U članku se analiziraju nesuglasice između Tita i Sukarna na Samitu u Kairu, oktobra 1964, oko ključnih prioriteta kojima bi trebalo da se rukovode nesvrstane zemlje u svojim zajedničkim akcijama u međunarodnim odnosima. Jugoslovenski zvaničnici su insistirali na formiranju jednog širokog pokreta, koji bi okupljao sve vanblokovske zemlje $i$ koordinisao njihovu delatnost u Ujedinjenim nacijama i široj sferi međunarodnih odnosa. U tom kontekstu, Tito je bio zagovornik borbe za izmenu postojećeg međunarodnog poretka nenasilnim putem, forsiranjem politike miroljubive koegzistencije. Sukarno je, pak, insistirao na okupljanju isključivo afro-azijskih zemalja u jedan regionalni pokret, čija bi delatnost bila usmerena isključivo na uže, lokalne probleme zemalja sa tog prostora. Smatrao je neminovnim sukob ,novih snaga“ - zemalja Trećeg sveta sa ,starim snagama“-zemljama okupljenim oko dvaju suprotstavljenih blokova. Stoga je odbacivao mogućnost koegzistencije između ovih dveju grupacija zemalja.

KLJUČNE REČI: blokovi, nesvrstane zemlje, Jugoslavija, Indonezija, Kina, Tito, Sukarno, kolonije, zemlje u razvoju, miroljubiva koegzistencija, regionalizam, saradnja

Ozbiljna razmimoilaženja i nesuglasice između lidera nesvrstanih zemalja oko ključnih pitanja koja su se ticala zajedničkih akcija ovih zemalja, davala su ton svim njihovim samitima. Od sposobnosti najuticajnijih protagonista politike nesvrstavanja da postignu opšteprihvatljiv kompromis u velikoj meri zavisio je ishod masovnih skupova, koji su pompezno pripremani, ali najčešće neslavno završavani (bar kada je reč o intenciji njihovog organizovanja). To je bio slučaj i sa konferencijama najviših predstavnika nesvrstanih zemalja u Beogradu i Kairu. U oba slučaja inicijatori skupova su se rukovodili idejom da je neophodno postići saglasnost među nesvrstanim

* Rad je deo projekta Srpsko društvo u jugoslovenskoj državi u 20. veku: između demokratije $i$ diktature, (177016), koji finansira Ministarstvo prosvete, nauke i tehnološkog razvoja Republike Srbije. 
zemljama oko potrebe formiranja stalnih, institucionalnih oblika njihovog povezivanja, odnosno oko obezbeđivanja uslova za stvaranje širokog pokreta koji bi okupljao sve aktere nesvrstane politike. Ali, u oba slučaja nije ostvaren željeni epilog.

U Beogradu je pomenuta ideja odbačena zbog bojazni da bi takav pokret prerastao u ,treći blok“, što bi izazvalo negativnu reakciju velikih sila, od kojih je većina nesvrstanih zemalja u to vreme primala obimnu ekonomsku i finansijsku pomoć.

U Kairu, pak, ovakva ideja nije mogla biti sprovedena u praksi, zbog nepostojanja jedinstvenog stava zemalja-učesnica oko ključnog pitanja: koje bi države konkretno trebale da čine članstvo u toj novoj međunarodnoj asocijaciji. Dakle, raniji otpor samoj ideji institucionalizacije saradnje nesvrstanih zemalja je uglavnom sveden na minimum, uporedo sa intenziviranjem procesa dekolonizacije koji je zahvatio afro-azijski prostor i uporedo sa naglim povećanjem broja država sa tog prostora koje su se opredelile za nesvrstanu politiku. Te države su postepeno prerastale u moćnu glasačku mašineriju u Ujedinjenim nacijama, što je aktuelizovalo potrebu njihovog organizovanog i kontinuiranog zajedničkog delovanja, kako u samoj Svetskoj organizaciji, tako i u široj sferi međunarodnih odnosa.

Tokom samita u Kairu, međutim, javlja se novi problem vezan za buduću saradnju i organizovan međunarodni nastup nesvrstanih zemalja, bez čijeg razrešenja nije bilo mogućno ići dalje. Samit u Kairu morao je razrešiti dilemu - da li prihvatiti Titov koncept univerzalizma ili Sukarnov koncept regionalizma; da li ići na okupljanje svih vanblokovskih država nezavisno od njihovog geografskog određenja ili formirati jedan regionalni pokret isključivo od država koje su pripadale afro-azijskom prostoru. ${ }^{1}$

U vreme kada ključni zagovornici nesvrstanosti (Egipat, Indija, Jugoslavija i Cejlon) pokreću prve inicijative za organizovanje novog samita vanblokovskih zemalja - otpočinju istovremeno pripreme za održavanje novog regionalnog, afro-azijskog skupa („Drugog Bandunga“, Konferencije afro-azijske solidarnosti). Glavni protagonista tog novog sastanka „bandunških zemalja“ bila je Indonezija, čiju inicijativu je odlučno podržavala Kina. Tako dolazi do „paralelizma inicijativa“ u sklopu nastojanja za povezivanjem i zajedničkim nastupom novooslobođenih zemalja iz Azije i Afrike i do svojevrsne trke protagonista održavanja skupa po uzoru na Samit u Beogradu 1961. i protagonista regionalnog samita po uzoru na Samit u Bandungu 1955.

Ideja o sazivanju novog Bandunga je već krajem 1963. i početkom 1964. godine nesumnjivo dobila krila, a Indonezija i Kina su različitim linijama pokušavale da izbore što širu podršku za hitno sazivanje pripremnog sastanka za ovu konferenciju afroazijskih zemalja. Pri tome su, svaka sa svoje strane, vodile snažnu kampanju protiv održavanja „konkurentske“ konferencije na kojoj bi učestvovale sve nesvrstane zemlje.

U indonežanskoj štampi je otvoreno osporavana svrsishodnost održavanja konferencije nesvrstanih zemalja i ukazivano na to „da takva konferencija ne bi bila

${ }^{1}$ Dragan Bogetić, „Rađanje i uobličavanje politike nesvrstanosti“, u: Tito - nesvrstanost - savremenost, Zbornik radova, urednici Bojana Tadić i Vladimir Falatov (Beograd: Memorijalni centar „Josip Broz Tito“, 1988), 143-153; Momir Stojković, Tito - Nehru - Naser. Nastanak i razvoj politike i pokreta nesvrstanosti (Zaječar: RO za grafičko-izdavačku delatnost, 1983); Leo Mates, Međunarodni odnosi socijalističke Jugoslavije (Beograd: Nolit, 1976). 
ni od kakve koristi“ i „da svakako ne bi mogla rešiti probleme koji se postavljaju pred nove zemlje“. Lider vodeće Nacionalne stranke i generalni sekretar prve Bandunške konferencije, Ali Sastroamiđojo, izjavio je da je „konferencija neangažovanih u kontradikciji sa planovima novih snaga koje se javljaju“. Indonežanski ministar inostranih poslova Subandario je skrenuo pažnju da se njegova zemlja „ne slaže sa ciljevima i vremenom održavanja“" te konferencije, a generalni sekretar Nacionalnog fronta Indonezije, Sudibito, izneo stav da pomenuta konferencija nesvrstanih, zapravo, „spasava imperijalizam“, a Konferencija afro-azijske solidarnosti „nastoji da ga likvidira". ${ }^{2}$

Predsednik Sukarno je u javnim nastupima bio vrlo ubedljiv kada je govorio o konkretnim razlozima zbog kojih bi afro-azijske zemlje trebale da daju prednost održavanju „Drugog Bandunga“, a ne konferenciji nesvrstanih zemalja. U prilog Sukarnovog stanovišta išla je sama činjenica što su afro-azijske zemlje praktično bile i jedine potencijalne učesnice konfrontiranih konferencija (sa izuzetkom Kube, Jugoslavije i Kipra). S obzirom na svoju regionalnu pripadnost i uže probleme za čije su razrešavanje bile životno zainteresovane, afro-azijske zemlje nisu imale interes da se debata o aktuelnim problemima Azije i Afrike razvodnjava i širi razmatranjem pitanja koja su se ticala evropskog i latinoameričkog prostora. U postojećoj situaciji činilo se logičnim da afro-azijske zemlje svoju pažnju i zajedničke akcije prvenstveno koncentrišu na konkretne sopstvene spoljnopolitičke prioritete, a ne na apstraktne doktrinarne stavove i smernice vezane za realizaciju dugoročnih globalnih rešenja i uzvišenih, ali u praksi neostvarljivih ideala. ${ }^{3}$

Kineske diplomate i političari nisu ni malo zaostajali za Indonežanima u kampanji za organizovanje nove konferencije afro-azijskih zemalja. Posebnu pažnju posvetili su Africi u kojoj je proces dekolonizacije u to vreme dosezao kulminaciju. S obzirom na snažne animozitete novooslobođenih naroda prema zapadnim kolonijalnim silama, u Pekingu su procenjivali da je u Africi „sjajna revolucionarna situacija“ i da sa zemljama tog prostora treba uspostaviti što prisnije kontakte. Rezultat takve procene, ali i nastojanja da se poveća broj pristalica nove Bandunške konferencije, bila je maratonska afrička turneja kineskog premijera Ču Enlaja, u sklopu proklamovane „misije dobre volje“. Kineski lider je u intervalu od 14. decembra 1963. do 2. februara 1964. posetio deset afričkih zemalja: UAR, Alžir, Maroko, Tunis, Ganu, Gvineju, Mali, Sudan, Etiopiju i Somaliju. Sa svojim domaćinima vodio je razgovore čiji je cilj bio suzbijanje sovjetskog uticaja na tom prostoru, predstavljanje Kine kao velike sile spremne da štiti novooslobođene afro-azijske narode od zapadnih sila i da im pruži svu potrebnu pomoć za njihovu ekonomsku emancipaciju. Ta pomoć je davana pod veoma povoljnim uslovima - besplatan transfer i beskamatni zajmovi. Ukupna finansijska pomoć Kine afričkim zemljama dostigla je tokom 1964. godine

${ }^{2}$ Arhiv Jugoslavije (AJ), Kabinet Predsednika Republike (KPR), I-4-a/4, Telegram Nikezića jugoslovenskim ambasadama u nesvrstanim zemljama, 30. januar 1964; Godišnjak Instituta za međunarodnu politiku i privredu. 1964 (Beograd: Institut za međunarodnu politiku i privredu (IMPP), 1965), $27-$ 29, 63-64, 82-83.

${ }^{3}$ Isto; Ljubodrag Dimić, Aleksandar Raković i Miladin Milošević, „Jugoslavija i Indonezija Tito i Sukarno 1945-1967. Prilog istoriji nesvrstanosti“, u: Jugoslavija - Indonezija 1945-1967, urednik Miladin Milošević (Beograd: Arhiv Jugoslavije, 2014), 85-88, 451-455. 
iznos od čak 88 miliona funti (ali je ipak bila četiri puta manja od sovjetske). Svoje domaćine Ču Enlaj je u velikoj meri uspeo da ubedi da, s obzirom na svoju kolonijalnu prošlost, imaju iste interese u međunarodnim odnosima kao i Kina i da su njihovi zajednički neprijatelji kako zapadne sile okupljene oko SAD, tako i Sovjetski Savez, nosilac „istočnog imperijalizma“ (u Kini se u to vreme ustalila doktrina o „dva imperijalizma“ - sovjetskom i američkom). ${ }^{4}$

Problem je bio u tome što su Indonežani, kao i Kinezi, forsirali beskompromisnu borbu „ugnjetenih i obespravljenih“ afro-azijskih naroda u cilju uništenja „eksploatatora“, koja ne samo što nije isključivala potencijalni svetski sukob, nego ga je svesrdno prizivala. Rukovodeći se hladnom i surovom logikom nudili su, u neku ruku, „laka i brza rešenja“ za složene međunarodne probleme. S druge strane, protagonisti konferencije nesvrstanosti (Tito, Naser, Sirimavo Bandaranaike) pokušavali su da im pariraju prilično apstraktnim parolama o nedeljivosti svetskog mira, uspostavljanju saradnje između konfrontiranih strana i obezbeđivanju uslova za izgradnju novog sistema međunarodnih odnosa, lišenih bilo kakve diskriminacije i primene politike sile. Ovakva polarizacija i paralelizam gledišta sve više su nosili opasnost stvaranja razdora unutar afro-azijskog sveta i među zemljama koje su se opredelile za vanblokovsku politiku. Sudar ovih dvaju koncepata je rezultirao zbunjenošću i kolebanjem većine nesvrstanih zemalja, koje nisu u to vreme imale do kraja iskristalizovane stavove u pogledu definitivne međunarodne strategije i spoljnopolitičkih prioriteta u svetskoj zajednici. Takva situacija podstakla je obe strane da ubrzaju pripreme za planirani skup. ${ }^{5}$

I pored intenzivirane diplomatske ofanzive zvaničnika iz Pekinga i Džakarte, pripremni sastanak za Konferenciju afro-azijske solidarnosti nije održan početkom februara u Džakarti, kako je planirano, već sredinom aprila. Pošto je usledio tek posle pripremnog sastanka nesvrstanih u Kolombu, na kome je postignuta saglasnost o potrebi održavanja samita nesvrstanih zemalja (u oktobru) lišenog regionalnih odrednica skup u Džakarti imao je krajnje ograničen domašaj s obzirom na ispoljene pretenzije njegovih sazivača. ${ }^{6}$ Pokazalo se da kinesko-indonežansku inicijativu podržavaju samo Gana, Iran, Kambodža, Gvineja i Mali (pri čemu su poslednje tri države istovremeno podržavale i ideju o održavanju konferencije nesvrstanih zemalja). U Džakarti je usvojen zaključak da Druga afro-azijska konferencija na nivou šefova država ili vlada otpočne rad 10. marta 1965. u Africi, u zemlji koju izabere Organizacija afričkog jedinstva.?

Bolji ukupan bilans u iscrpljujućoj trci protagonista dva relativno komplementarna koncepta okupljanja nesvrstanih zemalja - ostvarili su ipak zagovornici održa-

${ }^{4}$ AJ, KPR, I-4-a/4, Pripremni sastanak za Drugu konferenciju neangažovanih zemalja; Godišnjak Instituta za međunarodnu politiku i privredu. 1964, 539-540.

${ }^{5}$ AJ, KPR, I-4-a/4, Telegram Nikezića jugoslovenskim ambasadama u nesvrstanim zemljama, 30. januar 1964; Godišnjak Instituta za međunarodnu politiku i privredu. 1964, 27-29, 63-64, 82-83.

${ }^{6}$ Poseban problem je nastao jer se Kina suprotstavila mogućnosti da SSSR učestvuje na novoj Bandunškoj konferenciji uz argumentaciju da SSSR navodno nije azijska zemlja i da nije učestvovao na prvoj Bandunškoj konferenciji. Indonezija se, pak, suprotstavljala učešću Malezije s kojom je bila u sporu. Tako su potencirane nesuglasice među učesnicima konferencije i sporna pitanja o kojima nije postojala opšta saglasnost. Godišnjak Instituta za međunarodnu politiku i privredu. 1964, 64, 82-83.

${ }^{7}$ AJ, KPR, I-4-a/4, Pripremni sastanak za Drugu konferenciju neangažovanih zemalja. 
vanja šire konferencije, koja bi okupila sve vanblokovske zemlje. Njihova akcija je vrlo vešto inicirana iz Kaira, Nju Delhija, Kolomba i Beograda već januara 1964, kada se takoreći istovremeno u sve četiri metropole došlo do saznanja da se moraju ubrzati pripreme za samit nesvrstanih i da je neophodno preduhitriti indonežanskokinesku inicijativu. U tom pravcu svoju političku delatnost prvi je usmerio predsednik Izvršnog saveta Egipta, Ali Sabri, sugerišući jugoslovenskim zvaničnicima da se već u februaru održi „pretpripremni sastanak“ učesnica Beogradskog samita. Takav sastanak nije iziskivao veće pripreme i mogao se organizovati u kratkom roku, jer bi pomenute zemlje bile zastupljene preko svojih ambasadora akreditovanih u Kairu. Posle toga je planirano da se u maju ili junu održi širi pripremni sastanak ministara inostranih poslova svih vanblokovskih zemalja koje bi učestvovale na predstojećem samitu nesvrstanih. Jugoslovenski ministar inostranih poslova Koča Popović preneo je stav svoje vlade indijskom ambasadoru u Beogradu: „Raditi brzo i održati jednu pretkonferenciju u toku februara, ali paziti pri tome da se to ne predstavi kao protivteža Drugom Bandungu i da je to antikineski inspirisano". Tokom učestalih razgovora predstavnika Jugoslavije, Egipta i Cejlona postignuta je puna saglasnost u vezi sa pripremama za novu konferenciju nesvrstanih. Dogovoreno je da vlade ove tri zemlje upute zajednički poziv za održavanje pretpripremnog sastanka ambasadora svih učesnika Beogradskog samita, koji bi se održao u Kairu tokom februara 1964. Na tom pretpripremnom sastanku je trebalo utvrditi dnevni red, datum i mesto održavanja pripremnog sastanka za konferenciju i uputiti pozive ambasadorima nesvrstanih zemalja koji će na njemu učestvovati. ${ }^{8}$

Zbog izostanka interesovanja ostalih potencijalnih učesnika pretpripremnog sastanka, zemlje-inicijatori su odustale od njega, ali ne i od ideje o održavanju samita nesvrstanih. Na inicijativu predsednikâ Tita i Nasera i premijera Sirimavo Bandaranaike održan je od 23. do 28. marta 1964. Pripremni sastanak za predstojeću konferenciju šefova država ili vlada nesvrstanih zemalja. Sastanak je održan u Kolombu, prestonici Cejlona, uz prisustvo ambasadora 25 zemalja. ${ }^{9}$ Pozivu su se odazvale sve zemlje-učesnice Beogradskog samita osim Burme i Malija. ${ }^{10}$

$\mathrm{Na}$ ovom skupu potvrđena je privrženost svih učesnika politici nesvrstavanja, razmotrena su međunarodna zbivanja koja su se odigrala posle Beogradske konferencije i postignut dogovor o osnovnim detaljima značajnim za pripremu i održavanje

\footnotetext{
${ }^{8}$ AJ, KPR, I-4-a/5, Stavovi o Bandungu iz cirkularnih instrukcija u vezi sa novom konferencijom neangažovanih.

${ }^{9} \mathrm{Na}$ sastanku u Kolombu učestvovali su u punopravnom svojstvu: Avganistan, Alžir, Kambodža, Cejlon, Kongo Leopoldvil, Kuba, Kipar, Etiopija, Gana, Gvineja, Indija, Indonezija, Irak, Liban, Maroko, Nepal, Saudijska Arabija, Somalija, Sudan, Tunis, UAR, Jemen i Jugoslavija, a u svojstvu posmatrača: Brazil i Bolivija.

${ }^{10}$ Vlade Burme i Malija su u vreme iniciranja sastanka u Kolombu smatrale da ne bi bilo oportuno davati prednost Konferenciji nesvrstanih u odnosu na Konferenciju afro-azijskih zemalja, odnosno da ne bi bilo korisno prisustvovati prvoj konferenciji, a ostati po strani kada je u pitanju druga konferencija. Obe vlade su se, izjašnjavajući se za sopstveni put u socijalizam, tesno vezale za Kinu, sa kojom su sklopile važne ekonomske aranžmane od kojih je bitno zavisio njihov dalji privredni razvoj. Međutim, obe zemlje su kasnije izmenile svoj stav u pogledu okupljanja nesvrstanih i učestvovale su na Samitu u Kairu. Godišnjak Instituta za međunarodnu politiku i privredu. 1964, 565-566, 725-727; Diplomatski arhiv Ministarstva spoljnih poslova Republike Srbije (DA MSP), 1964, str. pov., 872, Rezime najvažnijih zaključaka Sastanka u Kolombu.
} 
Druge konferencije na vrhu (utvrđeni su projekt dnevnog reda, kriterijumi za učešće, rešeno je gde i kada će se održati konferencija). ${ }^{11}$

Zemlje učesnice Pripremnog sastanka utvrdile su privremeni dnevni red, koji je obuhvatao tri tačke: 1 . opšta debata o međunarodnoj situaciji; 2 . obezbeđenje i jačanje svetskog mira i unapređenje pozitivnih tokova kroz delovanje novih nacionalnih snaga; 3. podsticanje ekonomskog razvoja i ekonomske saradnje u svetu. Stratešku okosnicu ovakvog projekta činila je druga tačka dnevnog reda u kojoj je, u sklopu prvog paragrafa, kao prioritet svih prioriteta - bila markirana borba nesvrstanih zemalja za univerzalnu primenu politike miroljubive koegzistencije (što su inicijatori Pripremnog sastanka smatrali ključnim preduslovom za realizaciju svih ostalih prioriteta za koje se zalažu nesvrstane zemlje). ${ }^{12}$

Tek u okviru narednog paragrafa navedena je borba protiv imperijalizma, kolonijalizma i neokolonijalizma, koju su potencirali protagonisti formiranja regionalnog afro-azijskog pokreta. Time je prihvaćeno stanovište na kome je posebno uporno insistirala Jugoslavija - da se samo kroz opštu primenu načela politike miroljubive koegzistencije mogu realizovati ostali spoljnopolitički prioriteti nesvrstanih zemalja i da se samo u uslovima mira mogu obezbediti uslovi za eliminisanje imperijalizma i kolonijalizma u međunarodnim odnosima. ${ }^{13}$

Protagonisti indonežansko-kineskog gledišta izborili su, ipak, neku vrstu kompenzacije po ovom pitanju. U sklopu druge tačke privremenog dnevnog reda, naime, figurisala je formulacija u kojoj se prenaglašavala uloga „novih nacionalnih snaga“" (,new emerging forces“) u rešavanju međunarodnih problema. Ta formulacija se uklapala u indonežansko-kinesku formulu o neminovnosti sukoba „,novih“ $i$,starih snaga“" i u indonežansko-kinesko gledište o apsurdnosti stava da se odnosi između imperijalistički nastrojenih velikih sila i zemalja u razvoju mogu zasnivati na načelima miroljubive koegzistencije. ${ }^{14}$

U duhu pomenutih odluka sa Pripremnog sastanka održana je Druga konferencija šefova država ili vlada nesvrstanih zemalja, od 5. do 10. oktobra 1964. Na ovoj konferenciji, u svojstvu punopravnih učesnika, sudelovalo je 47 zemalja (na Beogradskoj 25), dok je u svojstvu posmatrača učestvovalo 10 zemalja i dva predstavnika međunarodnih organizacija (u Beogradu su bile zastupljene samo tri zemlje u ovom svojstvu). Za razliku od Beogradske konferencije, koja je formulisala osnovna načela i izradila platformu zajedničkog delovanja nesvrstanih, Kairska konferencija je otišla dalje i, prihvatajući ova načela u celini, razradila konkretan program akcije koji bi vodio oživotvorenju ovih načela. Tako su u završnom dokumentu Konferencije - Programu za mir i međunarodnu saradnju, navedene mere i sredstva čiji je cilj

${ }^{11}$ Odlučeno je da se Druga konferencija šefova država ili vlada nesvrstanih zemalja održi u Kairu, oktobra 1964. Radi završnih priprema uoči Konferencije, dogovoreno je da se održi ministarski sastanak kojem bi prisustvovale sve nesvrstane države. „Jugoslavija na Drugoj konferenciji neangažovanih zemalja. Pripreme za konferenciju“, Jugoslovenski pregled. Oktobar 1964, br. 10, (Beograd, 1965), 73.

${ }^{12}$ AJ, KPR, I-4-a/5, Potrebe i mogućnosti koegzistencije.

${ }^{13}$ AJ, KPR, I-4-a/5, Osnovni elementi naše platforme za novu konferenciju neangažovanih; AJ, KPR, I-4-a/5, Teze Državnog sekretarijata za inostrane poslove; AJ, KPR, I-4-a/5, Osnovne karakteristike govora predsednika Nasera; AJ, KPR, I-4-a/5, Govor Sirimavo Bandaranaike (Cejlon).

${ }^{14}$ DA MSP, 1964, str. pov, 872, „Nove snage“ (Indonežanska inicijativa). 
rešavanje kako političkih, tako i ekonomskih problema s kojima se suočavaju nesvrstane zemlje. ${ }^{15}$

Samit u Kairu se odvijao u znatno povoljnijoj međunarodnoj situaciji nego prethodna konferencija šefova država i vlada nesvrstanih zemalja u Beogradu. Tokom 1963. i 1964. godine, naime, došla su do izražaja nastojanja velikih sila da putem pregovora i konkretnih sporazuma pristupe rešavanju ključnih međunarodnih problema. Stoga se može reći da je to bilo vreme značajno popuštanja međunarodne zategnutosti i smanjivanja konfrontacije dveju blokovskih formacija. ${ }^{16}$ Ovakav obrt u velikoj meri bio je uslovljen postignutim paritetom u nivou naoružanja, koji je doveo do toga da su nuklearni rat, pa i Hladni rat, počeli da gube svoj prvobitan smisao. Kao sastavni element novih odnosa između velikih sila, javila se spremnost na pregovaranje, koja je vrlo brzo dala i konkretne rezultate. ${ }^{17}$

Elementi procesa detanta počeli su se u eksplicitnoj formi intenzivnije oblikovati već u vreme kada konačno dolazi do prevladavanja dramatičnih političkih i vojnih posledica Kubanske krize, koja je u jesen 1962. dovela svet na samu ivicu opšteg nuklearnog rata. ${ }^{18}$ Ova kriza je imala ogroman značaj za sagledavanje vojnih limita koje ni Amerikanci, ni Sovjeti nisu više bili spremni da pređu u međusobnom sukobu oko interesnih sfera, ma koliko važnosti polagali tim sferama i strateškim pozicijama. ${ }^{19}$ Nametao se zaključak da ni jedni ni drugi ne bi bili spremni da u krajnjem slučaju žrtvuju svoju bezbednost kako bi zaštitili bezbednost svojih saveznika.

Posledice i pouke Kubanske krize neminovno su dovodile u pitanje potrebu jačanja kohezije unutar vojnih saveza i prvi put izazvale značajna previranja, pa i nesuglasice, u odnosima između zemalja koje su bile „na istoj strani“. Aktuelna politika velikih sila zasnovana na Hladnom ratu morala je pretrpeti krupne promene. Najindikativniji u tom pogledu bio je nastup francuskog predsednika De Gola i njegove skeptične izjave o svrsishodnosti bližeg vezivanja Francuske za NATO, odnosno za SAD. Obrazlažući odrednice buduće francuske spoljne politike na konferenciji za štampu 29. jula 1963. on je istakao: „Do nedavno Amerikanci su zahvaljujući svom nuklearnom oružju mogli da daju slobodnom svetu gotovo potpunu zaštitu što se tiče odbrane. Ali, oni su izgubili taj monopol... Činjenica da i Rusi sada poseduju moć da

${ }^{15}$ DA MSP, 1964, str. pov., f-1, 9, Druga konferencija neangažovanih zemalja; Skupovi nesvrstanih zemalja 1961-1974 (Beograd: Međunarodna politika, 1974), 71-98; DA MSP, 1965, str. pov., f-1, 31, Međunarodna situacija i aktivnost Jugoslavije.

${ }^{16}$ AJ, KPR, I-4-a/5, Kretanja u 1963. godini; Bojana Tadić, Istorijski razvoj politike nesvrstavanja 1946-1966 (Beograd: IMPP, 1968).

${ }^{17}$ Radovan Vukadinović, Evropska sigurnost i suradnja (Zagreb: Globus, 1976); Dragomir Đokić, „Kontrola naoružavanja u Evropi (predlozi i inicijative 1946-1969)“, u: Materijali o evropskoj bezbednosti i saradnji (Beograd: IMPP, 1969), 177-264; Leo Mates, Međunarodni odnosi socijalističke Jugoslavije (Beograd: Nolit, 1976); Ljubivoje Aćimović, Problemi bezbednosti i saradnje u Evropi (Beograd: IMPP/Prosveta, 1978); Lidija Čehulić Vukadinović, Euroatlantizam i suvremeni međunarodni odnosi (Zagreb: Politička kultura, 2010); Džon Gedis, Hladni rat (Beograd: Klio, 2003); Ljubivoje Aćimović i Sonja Dapčević-Oreščanin, Materijali o evropskoj bezbednosti i saradnji (Beograd: IMPP, 1969).

${ }^{18}$ O eskalaciji i okončanju Kubanske krize videti: Spoljnopolitička dokumentacija. 1963, br. 1, (Beograd, 1963).

${ }_{19}$ „Pokušaji SSSR i SAD da se ostvari napredak u pregovorima o razoružanju“, Godišnjak Instituta za međunarodnu politiku i privredu. 1963 (Beograd: IMPP, 1964), 50-52. 
unište svet, uključujući Novi Svet, čini prirodnim to da Amerika gleda na svoj opstanak kao na glavni cilj eventualnog konflikta. To takođe čini prirodnim da će ona ocenjivati momenat, stepen i metod svoje nuklearne intervencije u odbrani drugih područja - posebno Evrope - u svetlosti ove presudne nužnosti“، ${ }^{20}$

Iz ovakve procene buduće američke strategije proizlazila je nužnost da zapadnoevropske države samostalno, svaka za sebe, razrade nove odbrambene planove $\mathrm{i}$ programe zasnovane na užim nacionalnim spoljnopolitičkim prioritetima (za pojedine članice NATO-a to se ogledalo, pored ostaloga, u povećanim naporima da dođu do sopstvenog nuklearnog oružja).

Amerika u očima Zapadne Evrope nije više bila pouzdan i svemoćan saveznik. Od momenta kada je SSSR proizveo impresivan arsenal nuklearnog oružja, Sjedinjene Države više nisu mogle da svojim saveznicima iz NATO-a obezbede zaštitu od Sovjeta, jer bi takva zaštita, u slučaju prerastanja Hladnog rata u oružani sukob Istoka i Zapada, neminovno završila potpunim uništenjem obe strane (pri čemu, činjenica da se u tom sklopu protivnik može višestruko uništiti zbog američke nadmoći u nuklearnom oružju - nije mogla predstavljati nikakvu utehu). Hladni rat, dakle, koji se kao i svaka politika sile zasnivao na pretnji, ostao je bez svoje glavne sadržajne odrednice. Efekat pretnje u konkretnoj situaciji poništen je obostranošću i nerealnošću te pretnje.

Cena Hladnog rata je uvek bila visoka, ali je ranije prihvaćena, jer se verovalo da ukupan rezultat opravdava žrtvu. Kada se, međutim, pokazalo da se Hladni rat ne može pretvoriti u pobedonosni pravi rat - smisao bespogovornog utapanja u vojne saveze se u velikoj meri izgubio. To se posle Kubanske krize itekako reflektovalo na spoljnopolitičke poteze SAD i na politiku članica NATO, ali i na međunarodnu strategiju Istočnog bloka, koja je sada bila koncentrisana na čitav niz mirovnih inicijativa (u čemu su naročito prednjačili SSSR i Poljska).

Posebnu pažnju u ovo vreme privukao je Kenedijev pomirljiv govor održan 10. juna 1963. na Američkom univerzitetu u Vašingtonu, kojim je promovisana nova spoljnopolitička koncepcija SAD - ,strategija mira“. Ta strategija se suštinski razlikovala od dotadašnje američke spoljnopolitičke koncepcije - politike konteinmenta (odnosno suzbijanja širenja sovjetskog uticaja u svetu), koju su odlučno sprovodili svi Kenedijevi prethodnici. Suština ove strategije se svodila na obezbeđivanje uslova za uspostavljanje trajnog mira između Istoka i Zapada, zasnovanog na pravdi, slobodi i pravu samoopredeljenja. Težište „strategije mira“ bilo je u nastojanju da SAD i SSSR izađu iz začaranog kruga Hladnog rata. Da bi se to postiglo, po Kenediju, bilo je neophodno da obe strane preispitaju svoje stavove prema pitanju miru, Hladnog rata i međusobnih odnosa. Pod mirom, kako je objasnio Kenedi, ne podrazumeva se „američki mir“, koji bi bio nametnut svetu američkom vojnom silom, nego mir u kome bi vladala uzajamna tolerancija i pravedno i mirno rešavanje međunarodnih problema. Imajući u vidu sveže iskustvo povezano sa dramatičnim izazovima koje je nedavno donela Kubanska kriza, upozorio je: „Nuklearne sile moraju da izbegavaju takve konfrontacije koje drugu stranu stavljaju pred dilemu - ili ponižavajuće povlačenje ili nuklearni rat". Kenedi je podsetio na činjenicu da SAD i SSSR nikad nisu

${ }^{20}$ Godišnjak Instituta za međunarodnu politiku i privredu. 1963, 10-11. 
bili u ratu jedni protiv drugih i svečano obećao da Sjedinjene Države nikad neće biti prve koje će otpočeti rat, da one ne žele rat i ne očekuju ga. ${ }^{21}$

Istočnoevropske zemlje su pozitivno reagovale na pomirljive izjave zvaničnika iz Vašingtona. Ponovo su obnovile inicijative za uspostavljanje bezatomske zone u Centralnoj Evropi i održavanje sveevropske konferencije o miru i bezbednosti, na kojoj bi učestvovale i Sjedinjene Države. Ovakve predloge pokrenuli su poljski ministar inostranih poslova Adam Rapacki, marta 1962, poljski predsednik Vladislav Gomulka, 29. decembra 1963. i 29. februara 1964, kao i vlada SSSR-a: maja 1963. i u jesen 1964. na XIX zasedanju Generalne skupštine UN. ${ }^{22}$

Iako se napetost među blokovima smanjivala, odnosi u svetu bili su veoma daleko od trajnog mira. Tokom 1963. i 1964. godine ideološki sukob između SSSR-a i Kine prerastao je u međudržavni. Situacija u svetu se dodatno komplikovala jer je Kina u vreme priprema i održavanja Kairskog samita okončala završne pripreme za svoju prvu nuklearnu eksploziju, koju je izvela nedelju dana posle ovog samita, 16. oktobra 1964. Trka u naoružanju se i inače nastavila, a na području nerazvijenog dela sveta odnosi su postajali sve složeniji. Osnovno težište blokovskog sukoba prebačeno je sa terena direktne međusobne konfrontacije na teren indirektne konfrontacije, stvaranjem novih žarišta kriza na područjima Azije i Afrike. U njima su velike sile bile na suprotnim stranama, ali ne neposredno suprotstavljene kao do tada. U najvećem broju lokalnih sukoba toga vremena velike sile su pružale podršku nekim stranama u sukobu, težeći da ojačaju sopstveni uticaj u pojedinim delovima sveta. To se posebno osećalo u sklopu eskalacije unutrašnjih sukoba podsticanih spoljnim mešanjem na prostoru Jugoistočne Azije (Vijetnam, Kambodža, Laos), u Kongu, Gabonu, Keniji, Tanganjiki i Ugandi. Američka blokada Kube i sukob dve etničke zajednice (turske i grčke) na Kipru, posebno su doprineli porastu tenzija u svetu. ${ }^{23}$

Iako su zemlje koje su učestvovale na Konferenciji u Kairu uglavnom ispoljavale visok stepen istovetnosti stavova u pogledu svih značajnijih međunarodnih problema i kriza - nikako se ne bi moglo reći da je ovaj samit protekao u atmosferi lišenoj krupnih razmimoilaženja, nesuglasica i neslaganja. Nesaglasnosti su se ticale koncipiranja konkretne strateške orijentacije tih zemalja, koja bi vodila razrešenju tih problema i žarišta kriza u svetu. Kao i obično, pokazalo se da je lako markirati sve ono što nesvrstani osuđuju, ali da nije ni malo lako formulisati buduće prioritete zajedničke akcije tih zemalja, koji treba da omoguće eliminaciju svega onoga što je predmet osude.

Polazilo se, doduše, od opšteprihvaćenog stanovišta da se svet više ne suočava sa opasnošću sukoba dveju supersila i dveju blokovskih formacija (kao što je to bio slučaj u vreme kada se održavao prethodni samit nesvrstanih u Beogradu). Do polarizacije gledišta, međutim, došlo je oko pitanja da li u takvoj izmenjenoj situaciji politika nesvrstanosti - gubi svoj nekadašnji smisao. Aktuelizovala se dilema: da li zadržati raniji kurs ili se sa novonastalom situacijom javljaju i novi izazovi, koji bi morali

${ }^{21}$ Keesing's Contemporary Archives, 1963, 19537A; Hronika međunarodnih događaja, 1963 (Beograd: IMPP, 1964), 101A.

${ }^{22} \mathrm{Lj}$. Aćimović i S. Dapčević-Oreščanin, $n$. $d$; ; L. Čehulić Vukadinović, $n$. $d$. press, 1981).

${ }^{23}$ Olivera Bogetić i Dragan Bogetić, Nastanak i razvoj pokreta nesvrstanosti (Beograd: Export- 
predstavljati uporišnu tačku bitno izmenjene i mnogo agresivnije buduće zajedničke aktivnosti, ne samo nesvrstanih nego i svih zemalja u razvoju. Bilo je mišljenja da tim zemljama uopšte nije pogodovao aktuelan detant u odnosima velikih sila. Sasvim suprotno, zemlje u razvoju su okarakterisane kao žrtve novog obrta u međunarodnim odnosima, jer se pritisak velikih sila preneo isključivo na njih i one su sada postale jedina meta agresivne imperijalističke politike tih sila. U skladu sa ovakvim stanovištem bila je i procena da je aktuelno stanje u međunarodnim odnosima teže od onog uoči Beogradskog samita, da se uopšte ne može govoriti o globalnom popuštanju tenzija i da detant u odnosima dveju supersila predstavlja nagodbu ,levog“ i ,desnog“ imperijalizma na štetu ostalog dela sveta. Stoga bi jedini prioritet zajedničke i organizovane akcije zemalja Trećeg sveta trebalo da bude odlučna i beskompromisna borba protiv imperijalizma, kolonijalizma i neokolonijalizma, pa i po cenu izbijanja opšteg svetskog sukoba. ${ }^{24}$

Odmah posle svečanog otvaranja Samita, dolazi do vidnih nesuglasica među liderima vanblokovskih država oko ključnog pitanja tog skupa - „,kakva treba da bude uloga nesvrstanih u svetu lišenom konfrontacije svrstanih". Od prvog momenta kada je u Kairu otvorena generalna debata (6. oktobra), o ovom pitanju iskristalizovala su se dva suprotna gledišta. Najmarkantniji predstavnici tih suprotstavljenih gledišta bili su Sukarno i Tito.

Sukarno je smatrao da vanblokovske zemlje nemaju više razloga da strahuju od sukoba dvaju suprotstavljenih blokova, jer su lideri tih blokova svesni da u opštem nuklearnom ratu ne bi bilo pobednika i da bi i sami bili izloženi totalnom uništenju. Stoga je miroljubiva koegzistencija mogućna među njima i nesumnjivo predstavlja njihovu dugoročnu spoljnopolitičku orijentaciju, a nesvrstane zemlje više nemaju potrebu da pokreću miroljubive inicijative (kao u vreme Beogradskog samita) u cilju smirivanja tenzija između blokova. U novonastaloj situaciji, međutim, samo se još više pogoršao međunarodni položaj nesvrstanih zemalja, jer je popuštanje zategnutosti između supersila išlo na njihovu štetu, budući da su velike sile još više pojačale pritisak na njih. U situaciji kada su nesvrstane zemlje okružene vojnim bazama velikih sila, koje vrše oštar vojni pritisak na njih i na najbrutalniji način se mešaju u njihova unutarpolitička pitanja - one ne mogu da žive u miru sa tim zemljama. Miroljubiva koegzistencija nije mogućna između zemalja u razvoju i velikih sila, koje sprečavaju te zemlje da u skladu sa sopstvenim nacionalnim interesima samostalno razvijaju svoj ekonomski i politički sistem. Sukarno je u više navrata postavljao retoričko pitanje: „Kako mi možemo koegzistirati i uporedo mirno živeti sa našim neprijateljima?“. Stoga je kao svojevrstan bojni poklič na Kairskom samitu forsirao odlučnu borbu protiv imperijalizma i neokolonijalizma i isticao neminovnost sukoba između „novih snaga“ (Trećeg sveta) i ,starih snaga“ (zemalja okupljenih oko SAD i SSSRa). Procenjivao je da će zemlje u razvoju moći slobodno da žive tek onda kada „u korenu uguše“ i potpuno neutrališu ,stare snage“. U tom smislu, glavni spoljnopoliti-

${ }^{24}$ AJ, KPR, I-4-a/5, Druga konferencija neangažovanih zemalja, Kairo, 5-10. oktobar 1964; Jugoslovenski pregled. Oktobar 1964, 73-90; DA MSP, 1964, str. pov., f-1, 9, Druga konferencija neangažovanih zemalja; Hronika međunarodnih događaja. 1964 (Beograd: IMPP, 1965), 440-444; „Konferencija u Kairu“, Godišnjak Instituta za međunarodnu politiku i privredu. 1964, 65-80. 
čki prioritet „novih snaga“ bio je da se udruže i ojačaju međusobnu solidarnost, a idealnu priliku da se osmisli takav proces Sukarno je video u budućoj Konferenciji afro-azijskih država i formiranju njihovog regionalnog pokreta. Što se tiče same politike nesvrstanosti, indonežanski predsednik je izrazio mišljenje da je ona predstavljala jednu fazu razvoja politike zemalja Trećeg sveta koja pripada prošlosti i da od Kairske konferencije nastupa „novo razdoblje“ u kome će ključna uloga pripasti „novim snagama“. ${ }^{25}$

Odmah posle Sukarna, u generalnoj debati nastupio je Tito. On je mnoge postavke iz izlaganja svog prethodnika ocenio kao ,štetne“ i „neprihvatljive“. Oštro je kritikovao Sukarnovo stanovište da u uslovima aktuelnog popuštanja zategnutosti između suprotstavljenih blokova, miroljubiva koegzistencija gubi svoj smisao i vodi trajnom konzerviranju novonastalog stanja u kome su nesvrstane zemlje još više bile izložene pritiscima i vojnim intervencijama velikih sila. Tito je generalno odbacio Sukarnovu ocenu bipolarnog detanta kao fenomena koji je negativno uticao na položaj nesvrstanih zemalja u međunarodnim odnosima. Polazio je od sasvim suprotnog stanovišta, smatrajući da je smirivanje tenzija u odnosima velikih sila doprinelo ne samo otklanjanju neposredne opasnosti od nuklearnog rata, nego i stvorilo bolje uslove za borbu protiv kolonijalizma i imperijalizma. Titu nije bila prihvatljiva Sukarnova teza da je miroljubiva koegzistencija mogućna samo u slučajevima kada postoji ravnoteža snaga, odnosno kada su u pitanju države jednake snage, a ne u odnosu između imperijalističkih sila i zemalja u razvoju. Insistirao je na tome da je miroljubiva koegzistencija jedina alternativa opštem ratu i da se stoga mora primenjivati i u odnosima između velikih sila, i u odnosima između tih sila i vanblokovskih država. Suprotan prilaz je ocenio kao svojevrsno prizivanje spoljnopolitičkih poteza kojima se „propovijeda potreba i korisnost ponovnog zaoštravanja međunarodnih odnosa, pri čemu se ne isključuje ni mogućnost opšteg ratnog sukoba“. Složio se sa Sukarnom „da bez slobode nema mira“, ali ga je istovremeno i upozorio „da bez mira nema slobode“ ${ }^{26}$

Ostali učesnici nisu bili toliko eksplicitni u pogledu davanja prednosti politici miroljubive koegzistencije ili borbi protiv imperijalizma i neokolonijalizma. Većina je, kao i jugoslovenski predsednik, ukazivala na stalnu međusobnu uslovljenost ovih dvaju fenomena, ali pri tome nisu ispoljavali kritičnost prema Sukarnovom prilazu. Jedino je u nastupu predsednika Malija Modiba Keite i predsednika Gvineje Seku Turea korišćena takoreći identična argumentacija kao u slučaju Indonezije, koja se svodila na odlučno forsiranje teze o neminovnosti sukoba „novih“ i ,starih snaga“ i o

${ }^{25}$ AJ, KPR, I-4-a/5, Osnovne karakteristike govora predsednika Sukarna.

${ }^{26}$ „Govor predsednika Tita na generalnoj debati“, Skupovi nesvrstanih zemalja 1961-1974, 9198. Tito je, istovremeno, oštro kritikovao i aktuelnu politiku koju vode blokovske sile. „Htio bih na ovom mjestu da ukažem na neka štetna shvatanja kojima se želi da opravda politika intervencije. Polazi se, naime, od toga kao da je mogućno u jednoj oblasti prihvatiti mir i koegzistenciju, a u drugim, takozvanim perifernim područjima, ili u odnosima s malim zemljama, braniti svoje interese silom i pritiskom, pozivajući se na ideološke ili druge motive i oslanjajući se na hladnoratovske metode. Pri tome, kao da se računa da druga strana ne bi htjela da reaguje, radi mira, i da će narodi koji su tome izloženi biti prisiljeni da prihvataju takvu politiku. U stvari, ovi krugovi bi želeli da koegzistenciju zlonamjerno tumače kao održavanje političkog status kvoa u oblastima gdje još postoje ostaci kolonijalizma i odnosi zavisnosti, ili da je pogrešno objašnjavaju kao zaustavljanje društvenog razvitka“. Isto, 96. 
prevaziđenosti politike nesvrstavanja kao „statičnog koncepta“, koji je u koliziji sa savremenošću i koji više ne odgovara interesima afro-azijskih naroda. U tom smislu, isticano je da je osnovni zadatak političke akcije nesvrstanih - suprotstavljanje imperijalizmu i kolonijalizmu, a da uspešna borba za očuvanje mira u svetu nije mogućna sve dotle dok se ne obezbede uslovi za razvoj nerazvijenih zemalja čime bi one postale ravnopravni partneri u međunarodnim odnosima sa drugim državama sveta. ${ }^{27}$

Tito i Sukarno su pokušali da u određenoj meri ublaže međusobne nesuglasice i različit prilaz prioritetima politike nesvrstanosti na sastancima koje su upriličili tokom održavanja Samita u Kairu. ${ }^{28}$ U razgovorima vođenim 5. i 10. oktobra 1964, Tito je ukazao Sukarnu na činjenicu da su se na Konferenciji u Kairu ,manifestovale velike razlike u gledištima između Jugoslavije i Indonezije“. Sukarno se složio s time uz ocenu ,da se među braćom često pojavljuju razlike, a ponekad i svađe, ali (da) to ne znači da je među njima došlo do stvarnog rascepa“. Ohrabren ovakvim Sukarnovim nastupom, jugoslovenski predsednik je pokušao da i sam doprinese smanjivanju tenzija, relativizujući suštinu spora uz opasku ,da nas Indonežani nisu dobro razumeli kada su se okomili na koegzistenciju“, jer ,mi ne shvatamo koegzistenciju bukvalno kao dalje održavanje postojećeg stanja“, već kao politiku koja „treba da nam omogući da sva pitanja rešavamo na miroljubiv način, a ne putem rata“. Upravo je ova opaska podstakla Sukarna da ukaže Titu kako se ovde ne radi ni o kakvom nesporazumu između njih dvojice, već o sasvim suprotnim gledištima u pogledu osnovnih pitanja oko odnosa prema ratu i miru. Sukarno je podsetio svog sagovornika da ni Jugoslavija ni Alžir ne bi izborili svoju nezavisnost bez oružane borbe. Izneo je svoju ocenu da Kairska konferencija može ,biti interesantna za azijsko-afričke zemlje samo onda, ako tačka broj jedan na njenom dnevnom redu bude osuda i borba protiv imperijalizma, kolonijalizma i njegovog novog oblika - neokolonijalizma“. Tito je zajedljivo odgovorio „da sve probleme treba staviti na prvo mesto“, da se navedeni problemi mogu rešavati „samo u miru, a ne putem rata“, dakle, da nije bitan redosled tema već „kako treba postaviti borbu protiv kolonijalizma i imperijalizma““ ${ }^{29}$

Budući da je Sukarno bio sumnjičav u pogledu svrsishodnosti održavanja Kairskog samita ukoliko bi na njemu prevagu odnela stanovišta koja su zastupali Tito i ostali inicijatori tog skupa, a istovremeno isticao značaj predstojećeg afro-azijskog samita - otvorilo se i drugo pitanje oko koga su se ozbiljno sporila dvojica sagovornika. Radilo se o dilemi da li nesvrstane zemlje treba uopšte da se na svojim skupovima bave putevima razrešenja širokih, globalnih problema ili da se isključivo kanališu na rešavanje sopstvenih lokalnih, užih, egzistencijalnih pitanja, vezanih za afroazijski prostor. Sukarnovom stanovištu - da prioritet na Samitu treba da ima isključivo zaštita interesa azijskih i afričkih država - Tito je suprotstavio potrebu zaštite

${ }^{27}$ AJ, KPR, I-4-a/5, Govori šefova delegacija. Predsednik Malija Modibo Keita dao je izjavu dopisniku Pravde u kojoj je istakao ,da je koncepcija neangažovanosti prevaziđena i da naredni zadaci borbe za nacionalno oslobođenje i progres traže nove forme“. AJ, KPR, I-4-a/5, Bilten, br. 9, 9. oktobar 1964, Informacije u vezi nove konferencije neangažovanih.

${ }^{28}$ Lj. Dimić, A. Raković i M. Milošević, $n$. $d$.

${ }^{29}$ AJ, KPR, I-4-a/5, Zabeleška o razgovoru druga Predsednika sa Predsednikom Republike Indonezije Sukarnom, 5. oktobar 1964; Poseta Predsednika Sukarna Predsedniku Titu, 10. oktobar 1964; Lj. Dimić, A. Raković i M. Milošević, $n$. d., 85-88, 451-455. 
interesa svih zemalja u razvoju, a samim tim i legitimnih interesa naroda Latinske Amerike, koji takođe žele „da se emancipuju, da se s nekim udruže i na nekog oslone“. Tito je smatrao da se te države „mogu osloniti samo na neangažovane zemlje“ $i$ da stoga neangažovane zemlje imaju „obavezu“ da im pomognu. Sukarno je, pak, ukazivao i na „drugi kanal“ pomoći - Konferenciju afro-azijskih zemalja, koja na prvo mesto stavlja borbu protiv imperijalizma i koja stoga mora biti mnogo privlačnija tim zemljama (o čemu svedoči činjenica da u latinoameričkim zemljama usvajaju „njegove ideje“). Ovakvo rezonovanje Tito je okvalifikovao kao „isuviše uprošćeno", ali njegov sagovornik na to nije odreagovao. U jugoslovenskoj dodatnoj zabelešci o razgovorima dvojice državnika formulisana je napomena u vezi sa dilemom: da li je ,prečuo primedbu“ ili se jednostavno „napravio da je nije čuo“. ${ }^{30}$

Pošto dvojica ključnih protagonista suprotstavljenih koncepata o prioritetima politike nesvrstanosti nisu uspela ni u najmanjoj meri da ublaže svoje nesuglasice, nije bilo realno očekivati da će se rad na Završnom dokumentu skupa odvijati u povoljnoj atmosferi i konstruktivnom duhu. Doduše, kako je Konferencija u Kairu sve više odmicala i približavala se kraju stvarao se privid da se razlike u stavovima pojedinih učesnika sve manje ispoljavaju, a da nastupi lidera nesvrstanih zemalja u plenarnoj debati sve više postaju jednoobrazni, osim kada su u pitanju neka uža, lokalna pitanja. To je bilo karakteristično i za Beogradski samit 1961, a ustalilo se kasnije i na svim preostalim samitima nesvrstanih, jer se većina državnika tu držala relativno pasivno i nije pred sobom imala jasnu viziju perspektive i smisla daljih zajedničkih akcija nesvrstanih zemalja. Međutim, budući da je za narednu godinu predviđeno održavanje Druge konferencije afro-azijskih zemalja, koja je trebalo da bude u znaku jubileja - 10-godišnjice održavanja Bandunške konferencije, u pozadini svega toga itekako je postojala svojevrsna polarizacija stavova jednog dela učesnika Kairskog samita oko formulisanja buduće globalne strategije vanblokovskih zemalja i modaliteta institucionalizacije njihove saradnje. Ne samo što se uopšte nije iskristalizovao jedinstven stav oko toga ko bi bile članice budućeg pokreta i koja bi bila njegova generalna strateška orijentacija, nego se ispoljavalo nejedinstvo čak i po pitanju same svrsishodnosti formiranja tog pokreta. Stoga se sve više povećavalo strahovanje lidera zemalja koje su inicirale Kairski samit (Nasera, Sirimavo Bandaranaike i Tita, kojima je odlučnu podršku pružao indijski premijer Šastri), da će se i ovaj skup nesvrstanih završiti bez ikakvog konkretnog dogovora oko budućih akcija nesvrstanih i daljeg organizovanog zajedničkog nastupa u međunarodnim odnosima. ${ }^{31}$

Plenarno zasedanje se, po mišljenju ovih političara, pretvaralo u „debatni klub“ u kome svako pokušava da što više skrene pažnju na neka uža pitanja od lokalnog interesa, kako bi njegovi stavovi bili uključeni u Završni dokument Konferencije. U takvoj situaciji, svi izgledi su bili da će Završni dokument predstavljati samo

${ }^{30}$ Isto; AJ, KPR, I-4-a/5, Dodatak zabelešci o susretu predsednika Tita i predsednika Sukarna u Kairu.

${ }^{31}$ AJ, KPR, I-4-a/5, Susreti i razgovori sa šefovima delegacija (Zabeleška o razgovoru druga Predsednika sa predsednikom vlade Indije Šastrijem, 9. oktobar 1964; Poseta predsednika Tita Naseru, 10. oktobar 1964; Poseta predsednika Tita Kvame Nkrumahu, 10. oktobar 1964. u 10 časova); AJ, KPR, I-4-a/5, Informacije u vezi nove konferencije neangažovanih, 9. oktobar 1964. 
„listu lepih želja“, bez ikakvog principijelnog značaja i da posle Kaira neće više biti mogućno ponovo okupiti njegove učesnike. ${ }^{32}$

Tokom razgovora između lidera Egipta, Cejlona, Indije i Jugoslavije u vreme Kairske konferencije uočen je i drugi problem - nastojanje velikog broja nesvrstanih zemalja da se u Završni dokument unesu ,isuviše sporedne stvari“. Na taj način „razvodnjavao" bi se sadržaj glavnog dokumenta Samita. Naime, ministri i eksperti zemalja-učesnica Samita u radnim telima pripremali su dokument koji je bio suviše dug (preko 40 strana) i koji je ulazio u niz marginalnih detalja. Stoga je dogovoreno da ovaj posao preuzmu šefovi najaktivnijih i najeksponiranijih država na Samitu i u najkraćem roku obave ovaj zadatak (jer je već isticalo vreme za okončanje skupa). Pored pomenute „,̌etvorke“ u novoformirani redakcioni odbor predloženi su lideri Indonezije, Gvineje i Gane (Sukarno, Seku Ture i Nkrumah), jer su i te zemlje podnele kompletan predlog nacrta Završnog dokumenta. Dogovoreno je da dokument mora biti koncizan i jasan, da sadrži samo osnovne principe, a da bi sve ostalo trebalo preneti u poseban aneks, koji šefovi država ne bi potpisivali. Takav prilaz je ocenjen kao jedini način da se obezbedi da Završni akt zaista dobije karakter „državničkog akta"koji će naići na poštovanje svetske javnosti. ${ }^{33}$

Sudeći po obimu konačnog teksta Završnog dokumenta (Programa za mir i međunarodnu saradnju), koji je sveden na nešto više od desetak strana, može se izvući zaključak da su zagovornici „konciznosti“ i „sažetosti“ ovog deklarativnog akta uspeli da sprovedu svoj dogovor oko ovog pitanja. Taj dokument je nesumnjivo na izvestan način predstavljao svojevrstan kompromis šarolike grupe potpisnika, ali je istovremeno predstavljao i dokument u kome nije bilo nametanja stavova jednih zemalja drugim zemljama - dakle, dokument koji nije nastao nadglasavanjem već strpljivim usaglašavanjem stavova svih učesnika. ${ }^{34}$

Sudeći, međutim, po sadržajnim odrednicama Programa za mir i međunarodnu saradnju može se reći da je on, kao i ceo Samit, zadržao suviše uopšten manifestacioni karakter, tipičan za sva dokumenta koja sadrže kompromisne formule neophodne da pomire različite, a donekle i suprotne stavove. To je posebno došlo do izražaja u formulacijama koje su predstavljale pokušaj pomirenja izrazito inkompatibilnih stavova protagonista koncepta o neminovnosti sukoba „novih“ i „starih snaga“ i njihovih glavnih oponenata. Stoga u Završnom dokumentu nije izložen stav Konferencije u pogledu buduće zajedničke strategije zemalja učesnica tog skupa prema blokovskim silama - da li ići na otvorenu konfrontaciju sa tim silama ili bazirati odnose sa njima na načelima miroljubive koegzistencije; da li forsirati borbu protiv imperijalizma i neokolonijalizma kroz aktivnosti koje bi vodile ponovnoj eskalaciji Hladnog rata ili tu borbu voditi forsiranjem političkih procesa i sadržaja koji bi dalje doprinosili smirivanju tenzija u međunarodnim odnosima. Pored ove taktičke nedorečenosti, u tekstu Završnog dokumenta uopšte nije pomenuta potreba za preduzimanjem konkretnih koraka u pravcu formiranja Pokreta nesvrstanosti, iako su neke učesnice Kairskog skupa ovo pitanje smatrale glavnim prioritetom nesvrstanih, jer bez uspos-

\footnotetext{
${ }^{32}$ Isto.

${ }^{33}$ Isto.

${ }^{34}$ „Program za mir i međunarodnu saradnju“, Skupovi nesvrstanih zemalja 1961-1974, 75-88.
} 
tavljanja stalnih mehanizama saradnje nije bilo mogućno obezbediti efikasnu i kontinuiranu akciju vanblokovskih zemalja. ${ }^{35}$

Izostanak konsenzusa oko buduće zajedničke međunarodne strategije nesvrstanih i oko modaliteta institucionalizacije njihove saradnje (fizionomije i širine pokreta, koji bi okupljao te zemlje), sam po sebi, nagoveštavao je ozbiljnu krizu politike nesvrstavanja i dugoročno opadanje intenziteta i frekvencije zajedničkih akcija nesvrstanih zemalja. Šestogodišnja pauza potrebna za pripremu i organizovanje narednog samita ovih zemalja predstavljala je najdužu pauzu ove vrste koja će biti zabeležena u istoriji nesvrstanosti.

\section{IZVORI I LITERATURA}

- Arhiv Jugoslavije (AJ), fondovi: Kabinet Predsednika Republike (KPR); Centralni komitet Saveza komunista Jugoslavije (CK SKJ), 507; Predsedništvo SFRJ, 803.

- Diplomatski arhiv Ministarstva spoljnih poslova Republike Srbije (DA MSP), Politička arhiva (PA), Jugoslavija, 1973-1974.

- Keesing's Contemporary Archives, 1963.

- Aćimović, Ljubivoje. Problemi bezbednosti $i$ saradnje u Evropi. Beograd: IMPP/Prosveta, 1978.

- Aćimović Ljubivoje, i Sonja Dapčević-Oreščanin. Materijali o evropskoj bezbednosti i saradnji. Beograd: IMPP, 1969.

- Bogetić, Dragan. „Rađanje i uobličavanje politike nesvrstanosti“. U: Tito - nesvrstanost - savremenost, Zbornik radova. Urednici Bojana Tadić i Vladimir Falatov, 143-153. Beograd: Memorijalni centar „Josip Broz Tito“, 1988.

- Bogetić Olivera, i Dragan Bogetić. Nastanak i razvoj pokreta nesvrstanosti. Beograd: Export-press, 1981.

- Čehulić Vukadinović, Lidija. Euroatlantizam i suvremeni međunarodni odnosi. Zagreb: Politička kultura, 2010.

- Dimić Ljubodrag, Raković Aleksandar, i Miladin Milošević. „Jugoslavija i Indonezija - Tito i Sukarno 1945-1967. Prilog istoriji nesvrstanosti“. U: Jugoslavija Indonezija 1945-1967. Urednik Miladin Milošević, 7-89. Beograd: Arhiv Jugoslavije, 2014.

- Đokić, Dragomir. „Kontrola naoružavanja u Evropi (predlozi i inicijative 19461969)“. Materijali o evropskoj bezbednosti i saradnji. Beograd: IMPP, 1969.

- Gedis, Džon. Hladni rat. Beograd: Klio, 2003.

- Godišnjak Instituta za međunarodnu politiku i privredu. 1963. Beograd: IMPP, 1964.

- Godišnjak Instituta za međunarodnu politiku i privredu. 1964. Beograd: IMPP, 1965.

- Godišnjak Instituta za međunarodnu politiku. 1974. Beograd: IMPP, 1975.

${ }^{35}$ Isto; AJ, KPR, I-4-a/5, Politika miroljubive koegzistencije; AJ, KPR, I-4-a/5, Deklaracija Konferencije neangažovanih zemalja. 
- Hronika međunarodnih događaja, 1963. Beograd: IMPP, 1964.

- Hronika međunarodnih događaja. 1964. Beograd: IMPP, 1965.

- Mates, Leo. Međunarodni odnosi socijalističke Jugoslavije. Beograd: Nolit, 1976.

- Skupovi nesvrstanih zemalja 1961-1974. Beograd: Međunarodna politika, 1974.

- Stojković, Momir. Tito-Nehru-Naser. Nastanak i razvoj politike i pokreta nesvrstanosti. Zaječar: RO za grafičko-izdavačku delatnost, 1983.

- Tadić, Bojana. Istorijski razvoj politike nesvrstavanja 1946-1966. Beograd: IMPP, 1968.

- Vukadinović, Radovan. Evropska sigurnost i suradnja. Zagreb: Globus, 1976.

Dragan Bogetić

\author{
THE CONFLICT BETWEEN TITO'S CONCEPT OF UNIVERSALISM \\ AND SUKARNO'S CONCEPT OF REGIONALISM IN THE 1964 SUMMIT \\ OF NON-ALIGNED COUNTRIES IN CAIRO
}

\begin{abstract}
Summary
During the Conference of the leaders of non-aligned countries in Cairo, a problem related to the future cooperation and organized international performance of non-aligned countries occurred, without whose resolution it was not possible to go further. In fact, the clash was growing between some conference participants around an important question. Which states should actually be members of the movement? The summit in Cairo had to resolve the dilemma - whether to accept Tito's concept of universalism or Sukarno's concept of regionalism; whether to opt for the gathering of all the non-aligned countries, regardless of their geographical definition or to form one regional movement only from the countries that belonged to the Afro-Asian area.

An additional problem was that the countries participating in the Summit of Cairo, besides these strategic, technical and operational issues, needed to define their attitude towards the policy of peaceful coexistence. Until then no one had questioned the appropriateness of this policy. However, during the period immediately preceding the Summit in Cairo, in circumstances where the risk of direct block conflict was largely gone, the dilemma appeared: what should be the role of the non-aligned countries in a world freed from confrontation of the aligned?

The concept advocated by Sukarno was inspired by the Chinese doctrine of the inevitability of escalation of the international class struggle. Sukarno therefore repeatedly stressed that the main and only task of the non-aligned countries was opposition to the policy of imperialism and neo-colonialism. He considered the conflict between ,new“ and „old power“, „poor“ and „rich nation“, „,color" and „white“ to be inevitable. Tito rejected such views as dangerous and as an open invocation of a new world war. He believed that there was a direct correlation between the struggle against imperialism and neo-colonialism and the very policy of peaceful coexistence.
\end{abstract}


The lack of consensus about these key questions at the Summit in Cairo concerning the future strategic orientation of the non-aligned countries resulted in a long-lasting crisis of the non-alignment policy and in the absence of joint and organized action of non-aligned countries in the sphere of international relations.

KEYWORDS: blocks, non-aligned countries, United States, Soviet Union, China, Yugoslavia, Indonesia, Tito, Sukarno, regionalisam, universalisam, cooperation, colonialisam, peacefull kcoexistence.

\section{КОНФЛИКТ МЕЖДУ КОНЦЕПЦИЕЙ ТИТО УНИВЕРСАЛИЗМА И КОНЦЕПЦИЯ РЕГИОНАЛИЗМА СУКАРНО В САММИТЕ 1964 ГОДА НЕПРИСОЕДИНИВШИХСЯ СТРАН В КАЙРО}

\section{Резюме}

В ходе Конференции лидеров неприсоединившихся стран в Каире возникла проблема, связанная с вопросами будущего сотрудничества и совместного международного выступления неприсоединившихся стран. Без решения этих вопросов невозможно было продолжит сотрудничество. На самом деле все чаще высказывалось мнение некоторых участников конференции по поводу вопроса: какие государства должны быть членами движения? Саммит в Каире должен был решить дилемму: принять ли Тито концепцию универсализма или концепцию регионализма Сукарно; следует ли собирать все неприсоединившиеся страны независимо от их географического определения или сформировать одно региональное движение только из стран, принадлежащих к афроазиатскому региону.

Еще одна проблема заключалась в том, что странам, участвующим в Саммите в Каире, помимо этих стратегических, технических и оперативных вопросов, необходимо было определить их отношение к политике мирного сосуществования. До тех пор никто не сомневался в целесообразности этой политики. Однако, в период, непосредственно предшествующий Саммиту в Каире, в условиях, когда риск прямого конфликта между блоками в основном ушел, возникла дилемма: какова должна быть роль неприсоединившихся стран в мире, свободном от конфронтации выровненных?

Концепция, предложенная Сукарно, была вдохновлена китайской доктриной о неизбежности эскалации международной классовой борьбы. Поэтому Сукарно неоднократно подчеркивал, что главная и единственная задача неприсоединившихся стран - это противодействие политике империализма и неоколониализма. Он считал, что конфликт между «новыми» и «старыми сыл», между «бедными» и «богатыми странами», между «цветными» и «белыми» неизбежен. Тито отвергал такие взгляды, как опасные и открытые призывы к новой мировой войне. Он считал, что существует прямая связь между борьбой против империализма и неоколониализма и самой политикой мирного сосуществования. 
Отсутствие консенсуса на Саммите в Каире по этим ключевым вопросам в отношении будущей стратегической ориентации неприсоединившихся стран, привело к долговременному кризису политики неприсоединения и отсутствию совместных и организованных действий неприсоединившихся стран в сфере международных отношений.

КЛЮЧЕВЫЕ СЛОВА: блоки, неприсоединившиеся страны, Соединенные Штаты, Советский Союз, Китай, Югославия, Индонезия, Тито, Сукарно, регионализм, универсализм, сотрудничество, колониализм, мирное сосуществование 